\title{
SANITATION PRACTICES AND MICROBIAL QUALITY OF DRINKING WATER IN OPEN DEFAECATION FREE AND OPEN DEFAECATION COMMUNITIES IN THE SAVELUGU MUNICIPALITY
}

\author{
N. Bakobie, A. R. Ibrahim And A. B. Duwiejuah* \\ (N. B.: Department of Environment, Water and Waste Engineering, School of Engineering, \\ University for Development Studies, Tamale, Ghana; A. R. I.: Ecotourism and \\ Environmental Management, Faculty of Natural Resources and Environment, University \\ for Development Studies, Nyankpala Campus, Tamale, Ghana; A. B. D.: Department of \\ Biotechnology and Molecular Biology, Faculty of Biosciences, University for Development \\ Studies, Tamale, Ghana). \\ *Corresponding author's email: abalu096@gmail.com
}

\begin{abstract}
Open defaecation leads to faecal matter contamination of drinking water which can cause water borne diseases. The study assessed the linkage between sanitation practices and microbial quality of drinking water of open defaecation free and open defaecation communities in the Savelugu Municipality. A cross-sectional survey of 170 households was conducted in five open defaecation free and five open defaecation communities in the Savelugu Municipality. A total of 78 samples were collected from water sources and households and analysed for Escherichia coli, Salmonella spp and Shigella spp. Sanitation facilities used by the residents included pit latrine $(88.24 \%)$, no latrine $(11.17 \%)$, and flush $(0.59 \%)$. The study observed improper disposal of children faeces in the communities. E. coli count ranged from 0 to $15 \mathrm{CFU} / 100 \mathrm{ml}$ in open defaecation free communities and 0 to $32 \mathrm{CFU} / 100 \mathrm{ml}$ in open defaecation communities. The microbial load in the drinking water from open defaecation communities was higher than open defaecation free communities. Open defaecation practice leads to contamination of household water probable due to unsanitary. Community Led Total Sanitation (CLTS) should be encouraged in open defaecation communities.
\end{abstract}

Keywords: Community Led Total Sanitation, drinking water, open defaecation, open defaecation free, Salmonella spp

\section{Introduction}

In developing countries, most people do not have any form of sanitation services and access to clean water. As a result, millions of people are suffering from hygiene, water, and sanitation related diseases such as trachoma, skin diseases and diarrhoea (Muhammed et al., 2016). According to World Health Organisation (2017) 159 million people largely rely on surface water sources like rivers for drinking water whilst 423 million rely on unprotected springs for water that is connected to transmission of water-associated diseases.

The United Nations have affirmed sanitation as a right for human beings (WHO \& UNICEF, 2015). However, 2.6 billion people have no access to enhance sanitation whilst approximately 1.3 billion people are practising 
open defaecation, in nearly all developing nations and mostly in rural areas (WHO \& UNICEF, 2015). Lack of adequate sanitation contributes to contamination of drinking water particularly due to open defaecation which has health effect on the public. Open defaecation elimination is therefore seen as a main health outcome. The transfer of several diseases of microbial origin are through water which serves as vehicles. WHO reported that 1.8 billion people drink water polluted with Escherichia coli, which is an indicator of fresh faecal matter contamination (Bain et al., 2014)?

In Africa, Ghana has been ranked second in open defaecation, with almost 5 million people without any toilet facility (WHO \& UNICEF, 2015). In Ghana, 18.75\% people are reported to have been practising open defaecation in 2015 (World Bank, 2015). The prevalence of open defaecation practice is about $89 \%$ in the Upper East Region without any form of latrine, about $72 \%$ in Northern Region and about $71 \%$ in Upper West Region (WHO \& UNICEF, 2015).

Open defaecation deteriorates drinking water quality making it unfit for the purpose of drinking and increasing chances of water related diseases. Three people out of every five drink faeces contaminated water increasing people risk of contracting diseases which include cholera and diarrhoea. Diarrhoea causes over 3,600 deaths of Ghanaian children every year and cholera outbreaks happening in the cities frequently (United Nations International Children's Emergency Fund, 2017).

Northern Ghana has seen the coming and support of many partners with lots of monies going into the WASH (water, sanitation and hygiene) sector and yet the impact seem to be very minimal. The study was to assess the linkage between sanitation practices and microbial quality of drinking water of open defaecation free and open defaecation communities in the Savelugu Municipality.

\section{Experimental}

Study area

The study was carried out in some open defaecation free communities (Chahiyili, Lagbani, Damdu, Zaazi-Kukuo and Zaazi) and open defaecation communities (Libga, Balshei, Kanshegu, Yemo and Duko) of the Savelugu Municipal in the Northern Region, Ghana. Savelugu Municipality shares boundaries with East Mampurusi District to the North, Karaga District to the East, Tamale Metro to the South and Kumbungu to the West (Ghana Statistical Service, 2012). It has a total projected land size of $2022.6 \mathrm{sq} \mathrm{km}$ with 149 total communities out of which only 14 communities are open defaecation free. The Municipality lies between longitudes $0^{\circ} 36$ and $0^{\circ} 57$ West and latitude 9.6247222 and $9^{\circ} 34$ North (Ghana Statistical Service, 2012). 


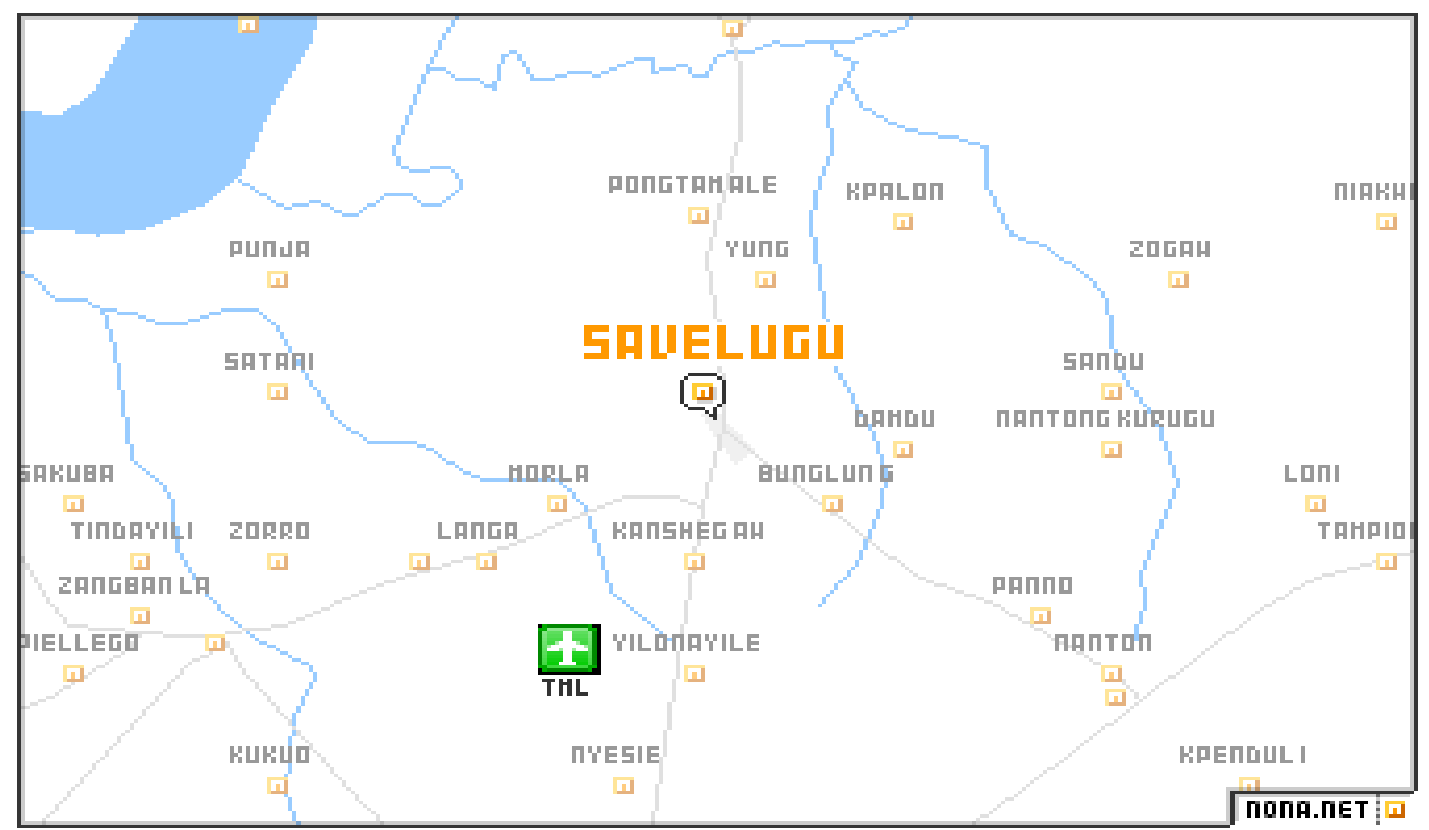

Fig. 1: Map of Savelugu Municipality.

\section{Qualitative data}

The Yamane formula was used at a $92 \%$ confidence and with $8 \%$ margin of error

$$
\mathrm{n}=\frac{N}{1+N\left(\partial^{2}\right)}
$$

$\mathrm{N}=$ sample frame, $1=$ a constant, $\mathrm{n}=$ sample size, and a margin of error, $\partial=0.008$.

The total population in the ten communities (five open defaecation free and five open defaecation communities) was 4,191 representing the sample frame and the sample size worked out to be 170 , using the formula above.

\section{Data collection}

A cross-sectional survey of 170 households was conducted in five open defaecation free and five open defaecation communities in the Savelugu Municipality. A cluster sampling technique was used to select open defaecation free and open defaecation communities from the Savelugu Municipality. Simple random sampling technique was then used to select 85 households from each community. Households with proximity to water sources and sources of drinking water within the study areas were given much consideration. A questionnaire was administered to 170 respondents. Information on access to sanitation and the disposing factors in relation to water pollution were obtained through observation and using questionnaire. The respondents consented and were assured of confidentiality before the face-face interview was conducted in the study. 
Household water sample collection

Samples were collected on weekly basis for three weeks from January to March 2018. A total of 78 samples were taken from water sources and household for Escherichia coli, Salmonella spp and Shigella spp. Each sampling bottle was rinsed three times with the water sample before filling. Samples were collected into $500 \mathrm{ml}$ plastic bottles after the content was rinsed three times with the sampling water at the site. Sample bottles were labelled appropriately and immediately placed in cold ice chests and transported to the water quality laboratory of the World Vision International, Savelugu for analysis.

\section{Bacteria analysis of water samples}

Using membrane filter technique, $100 \mathrm{ml}$ of water sample was passed through the membrane using vacuum system and a filter funnel. Water samples were collected aseptically. The appropriate culture medium was selective with respect to the target microorganisms. Sterile forceps were used to remove membrane filter from case and placed into the filter assembly. The lip of the pouring sample container was flamed before the water sample was poured into the filter funnel. The vacuum pump was turned on and water sample was allowed to draw out completely through the filter paper. The forceps was then flamed before it used to remove the membrane filter from the funnel. The filter paper was then placed in the Petri dish containing Methylene Blue (EMB) Agar for E. coli, and Xylose-Lysine Deoxycholate (XLD) Agar for Salmonella spp and Shigella spp. The Petri dish was then incubated for 18
- 24 hours incubated at $37^{\circ} \mathrm{C}$ (E. coli) and 18 24 hours at $37^{\circ} \mathrm{C}$ (Salmonella spp and Shigella $\mathrm{spp})$. Discrete colonies formed were then enumerated and calculated using the formula; bacteria colonies per $100 \mathrm{~mL}=$ bacteria colonies counted all divided by the $\mathrm{mL}$ of sample used $\times 100$ (American Public Health Association (APHA), 2017).

\section{Principal component analysis (PCA)}

Principal component analysis was used to compare the variability of bacteria at the open defaecation free and open defaecation communities. The model is a linear grouping of variables elucidating the matrix variance structure that condense the different data into a small number of principal component. The correlation between the bacteria counts in the drinking water were determined using Pearson's correlation.

\section{Results}

Demographic characteristics of the respondents

Of the 170 respondents interviewed, $67.65 \%$ of the respondents were females $(n=115)$ whilst $32.35 \%$ were males $(n=55)$ (Table 1$)$. The age of the respondents ranged from less than $24(43.52 \%), 25-44$ years was $29.42 \%$, 45 - 64 years was $21.18 \%$ and 65 years and above was $5.88 \%$ (Table 1). The respondents' education levels were no formal education $(72.35 \%)$, primary $(13.53 \%)$, senior high school $(11.74 \%)$, and tertiary $(2.35 \%)$ (Table 1). The marital status of the respondents were married $(40 \%)$, single $(44.12 \%)$ and widowed $(15.88 \%)$ (Table 1). 
TABLE 1

Demographic characteristics of the respondents.

\begin{tabular}{lll}
\hline Gender & Frequency $(\mathrm{N}=170)$ & Percent $(\%)$ \\
\hline Male & 55 & 32.35 \\
Female & 115 & 67.65 \\
Total & 170 & 100 \\
\hline Age & & \\
Less than 24 years & 74 & 43.52 \\
25 - 44 years & 50 & 29.42 \\
45 - 64 years & 36 & 21.18 \\
65+ years & 10 & 5.88 \\
Total & 170 & 100 \\
\hline Education & & \\
Primary/JHS Level & 23 & 13.53 \\
SHS & 20 & 11.74 \\
Tertiary & 4 & 2.35 \\
No formal & 123 & 72.35 \\
Total & 170 & 100 \\
\hline Marital status & & \\
Married & 68 & 40 \\
Widowed & 27 & 15.88 \\
Single & 75 & 44.12 \\
Total & 170 & 100 \\
\hline
\end{tabular}

Sanitation types in communities and cultural issues hindering

The kind of sanitation facilities used by the respondents included pit latrine $(88.24 \%)$, no latrine (11.17\%), and flush (0.59\%) (Table 2). The respondents that did not share latrine in the household were $92.5 \%$ and those that shared latrine were $5.88 \%$ (Table 2). This study found household size of two to three persons that shared latrine to be $5.29 \%$, four to five persons were $1.18 \%$ and those that did not share were 93.53\% (Table 2). 
TABLE 2

Sanitation types in the communities and cultural issues hindering.

\begin{tabular}{lll}
\hline What kind of toilet facility & Frequency $(\mathrm{N}=170)$ & Percent $(\%)$ \\
\hline Flush & 1 & 0.59 \\
Pit latrine & 150 & 88.24 \\
No latrine & 19 & 11.17 \\
Total & 170 & 100 \\
\hline Do you share the latrine & & \\
with any household & 10 & 5.88 \\
Yes & 160 & 94.12 \\
No & 170 & 100 \\
Total & & \\
How many household use the latrine & 9 & 5.29 \\
$2-3$ persons & 2 & 1.18 \\
4.5 persons & 159 & 93.53 \\
None & 170 & 100 \\
Total & & \\
\hline Do women and girls use the latrine & 169 & 99.41 \\
Yes & 1 & 0.59 \\
No & 170 & 100 \\
Total & & \\
\hline Do men and boys use the latrine & 169 & 99.41 \\
Yes & 1 & 0.59 \\
No & 170 & 100 \\
Total & & \\
&
\end{tabular}

\section{Factors associated with domestic water} contamination

\section{Households faecal disposal practices}

The methods of the child faeces disposal in the households were doing nothing $(48.82 \%)$, burying $(32.35 \%)$, and disposal into the latrine (18.82\%) (Table 3). Also, 94.71\% of the respondents admitted that they used to defaecate in bush / shrubs / forest in the community before CLTS, $3.53 \%$ defaecate in around the community and only 1.76 defaecate in public toilet (Table 3). The reasons for these practices were they did not have latrine (48\%), to burry or cover the faeces $(18.5 \%)$ and the place is close $(31.80 \%)$ (Table 3$)$. The survey showed $68.82 \%$ of the respondents admitted nothing good comes from defaecating openly (Table 3). Also, $79.41 \%$ of the respondents admitted exposure to snakes and scorpions when engaged in open defaecation. 
TABLE 3

Households faecal disposal practices.

\begin{tabular}{lll}
\hline $\begin{array}{l}\text { Last time the youngest child passed stool } \\
\text { what was done to it }\end{array}$ & Frequency $(\mathrm{N}=170)$ & Percent $(\%)$ \\
\hline Buried & 55 & 32.35 \\
Disposed in the latrine & 32 & 18.82 \\
Nothing & 83 & 48.82 \\
Total & 170 & 100 \\
\hline
\end{tabular}

Where did you defaecate before CLTS

Around the community 6

Bush / shrubs / forest in the community 161

Public toilet

Total

170

1.76

Why you did defaecate there

Did not have latrine

To burry or cover the faeces

The place is close

Total

170

100

What good did you observe defaecating there

Separated our faeces from the community

Covered our nudity

Nothing good

Total

What bad did you observe defaecating there

Exposure to snakes and scorpions

Exposure of our nudity

It is our cemetery

Others

Improvement of general well-being of the communities

Out of the 170 respondents, $94.70 \%$ respondents said CLTS had improved their well-being in the communities, only $5.30 \%$ people said CLTS had not improved their well- being in the communities (Table 4). Citing examples such as making them clean the whole community at least once every week, children not falling sick regularly, and they were now enjoying natural air due to clean and non-smelly environment. 
How sanitation can be maintained

Out of the 170 respondents, $11.77 \%$ were of the view that Municipal Environmental Health and Sanitation Unit (MEHSU) should continuously monitoring their communities, $30.58 \%$ said the continuous training of their sanitation committees will help sustain CLTS/ sanitation in their communities, whilst $57.65 \%$ said help from the Municipal Assembly will help sustain CLTS (Table 5).

TABLE 4

How CLTS/sanitation can be sustained.

\begin{tabular}{lll}
\hline Activity & $\begin{array}{l}\text { Frequency } \\
(\mathrm{N}=170)\end{array}$ & $\begin{array}{l}\text { Percent } \\
(\%)\end{array}$ \\
\hline $\begin{array}{l}\text { By continuous } \\
\text { monitoring by the }\end{array}$ & 20 & 11.77 \\
$\begin{array}{l}\text { MEHSU } \\
\text { By continuous } \\
\text { training of the } \\
\text { sanitation committee }\end{array}$ & 52 & 30.58 \\
$\begin{array}{l}\text { Help from the } \\
\text { Municipal Assembly }\end{array}$ & 98 & 57.65 \\
\begin{tabular}{l} 
Total \\
\hline
\end{tabular} & 170 & 100 \\
\hline
\end{tabular}

Household water sources and treatment in the communities

In the study, $91.18 \%$ of the respondents depend on borehole water (improved source of water) and only $8.82 \%$ depend on river / dam water (unimproved). Mostly, women who fetched water for the household uses of which majority spent 5 - 50 minutes to supply the household water. Also, $4.71 \%$ people responded they treated their household water whilst $95.29 \%$ respondents said they did not treat their water (Table 5). The various methods of water treatment in the households in various communities included filtration $(63.50 \%)$ and addition of alum (36.5\%) (Table 5).
TABLE 5

Household water sources and treatment in the communities.

\begin{tabular}{|c|c|c|}
\hline $\begin{array}{l}\text { What is your main } \\
\text { source of water for } \\
\text { cooking and washing }\end{array}$ & $\begin{array}{l}\text { Frequency } \\
(\mathrm{N}=170)\end{array}$ & $\begin{array}{l}\text { Percent } \\
(\%)\end{array}$ \\
\hline Borehole & 155 & 91.18 \\
\hline River/ dam & 15 & 8.82 \\
\hline $\begin{array}{l}\text { Who usually goes to } \\
\text { the source to fetch wa- } \\
\text { ter for your household }\end{array}$ & & \\
\hline Women & 124 & 72.94 \\
\hline Men and women & 28 & 14.12 \\
\hline $\begin{array}{l}\text { Children } \\
\text { How long does it take }\end{array}$ & 18 & 10.59 \\
\hline $\begin{array}{l}\text { to go there get water } \\
\text { and come back }\end{array}$ & & \\
\hline $5-15$ mins & 56 & 32.94 \\
\hline $16-30$ mins & 44 & 25.88 \\
\hline $31-40$ mins & 35 & 20.59 \\
\hline $41-50$ mins & 26 & 15.29 \\
\hline $60+\operatorname{mins}$ & 9 & 5.29 \\
\hline $\begin{array}{l}\text { Do you treat your wa- } \\
\text { ter in any way to make } \\
\text { it safer to drink }\end{array}$ & & \\
\hline Yes & 8 & 4.71 \\
\hline No & 162 & 95.29 \\
\hline $\begin{array}{l}\text { What treatment } \\
\text { method do you use }\end{array}$ & & \\
\hline Filtration & 108 & 63.53 \\
\hline Addition of alum & 62 & 36.47 \\
\hline
\end{tabular}

Bacteria in drinking water in open defaecation free and open defaecation communities

E. coli count ranged from 0 to $15 \mathrm{CFU} / 100$ $\mathrm{ml}$ with a mean of $1.05 \mathrm{CFU} / 100 \mathrm{ml}$ in open defaecation free communities and 0 to 32 $\mathrm{CFU} / 100 \mathrm{ml}$ with a mean of $2.79 \mathrm{CFU} / 100 \mathrm{ml}$ in open defaecation communities (Table 6). Salmonella spp ranged from 0 to $48 \mathrm{CFU} / 100$ $\mathrm{ml}$ with a mean of $2.38 \mathrm{CFU} / 100 \mathrm{ml}$ in open defaecation free communities and 0 to 48 CFU/100 ml with a mean of $3.23 \mathrm{CFU} / 100$ $\mathrm{ml}$ in open defaecation communities (Table 6). Shigella spp ranged from 0 to $31 \mathrm{CFU} / 100$ 
$\mathrm{ml}$ with a mean of $3.15 \mathrm{CFU} / 100 \mathrm{ml}$ in open defaecation free communities and 0 to 172
CFU/100 ml with a mean of $18.08 \mathrm{CFU} / 100$ $\mathrm{ml}$ in open defaecation communities (Table 6).

TABLE 6

E. coli, Salmonella spp and Shigella spp counts of the communities.

\begin{tabular}{lllll}
\hline Sample site & & $\begin{array}{l}\text { E. coli (CFU/100 } \\
\mathrm{ml})\end{array}$ & $\begin{array}{l}\text { Salmonella } \mathrm{spp} \\
(\text { CFU/100 ml) }\end{array}$ & $\begin{array}{l}\text { Shigella } \mathrm{spp} \\
\text { (CFU/100 ml) }\end{array}$ \\
\hline Open defaecation free & Min & 0 & 0 & 0 \\
Open defaecation free & Max & 15 & 31 & 48 \\
Open defaecation free & Mean & 1.05 & 3.15 & 2.38 \\
Open defaecation & Min & 0 & 0 & 0 \\
Open defaecation & Max & 32 & 172 & 48 \\
Open defaecation & Mean & 2.79 & 18.08 & 3.23 \\
\hline
\end{tabular}

TABLE 7

Correlation matrix of the bacteria.

\begin{tabular}{llll}
\hline Variables & E. coli & Salmonella $\mathrm{spp}$ & Shigella $\mathrm{spp}$ \\
\hline E. coli & $\mathbf{1}$ & & \\
Salmonella spp & $\mathbf{0 . 8 6 9}$ & $\mathbf{1}$ & \\
Shigella $\mathrm{spp}$ & $\mathbf{0 . 2 2 7}$ & 0.059 & $\mathbf{1}$ \\
\hline
\end{tabular}

Values in bold are different from 0 with a significance level alpha $=0.05$

The study showed $29 \%$ occurrence E. coli, $24 \%$ occurrence of Salmonella spp and Shigella spp in drinking water sampled from open defaecation free communities and $71 \%$ occurrence of E. coli, $76 \%$ occurrence of both Salmonella spp and Shigella spp in open defaecation communities (Figure 1).

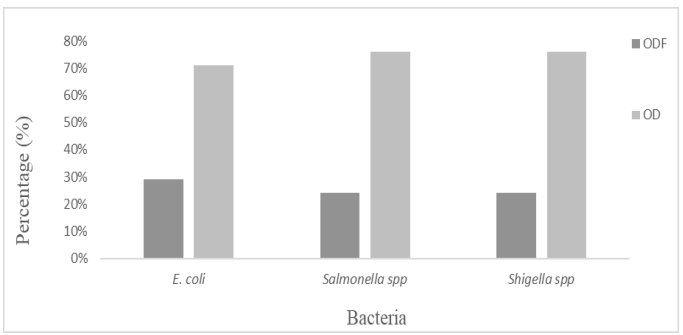

Fig. 1: Percentage of E. coli, Salmonella spp and Shigella spp occurrence in water sample.
Factors influencing bacteria contamination of the drinking water in open defaecation free and open defaecation communities

PCA was used to identify possible variability in bacteria count in sources of drinking water in the open defaecation free and open defaecation communities. Only one component of eigenvalue was greater than 1 extracted, accounting for $63.79 \%$ of total variance. The first two accounted for $97.17 \%$ of total variance, with PC1 (E. coli and Salmonella spp) accounting for the $63.79 \%$ of total variance (Figure 2). PC2 (Shigella spp) accounted for $32.38 \%$ of total variance, whilst PC3 accounted for $3.83 \%$ of total variance. This denoted the first distinction in the bacteria profiles in the open defaecation free and open defaecation communities (Figure 3). 


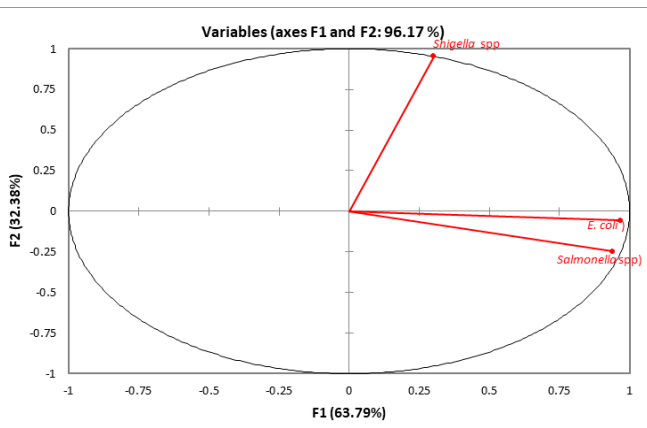

Fig. 2: Distribution of bacteria in the first and second principal component.

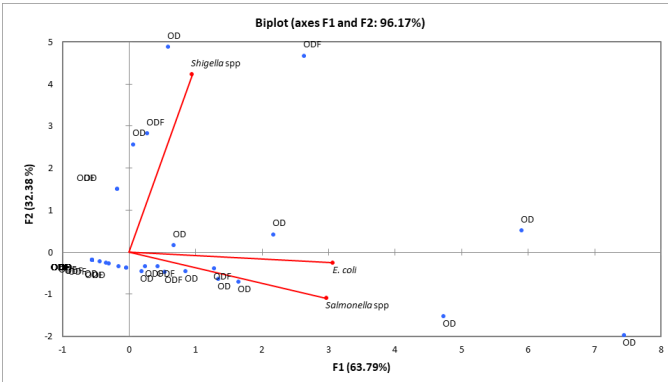

Fig. 3: PCA map of the 78 water samples from open defaecation free (ODF) and open defaecation (OD) communities and the bacteria.

\section{Discussion}

The all the people said they do not have any cultural issues hindering their use of latrines. The use of improved latrine is accompanied with good number of benefits to the household, an individual, and community (Bwire, 2010). The use and access to improved sanitation facilities can reduce open defaecation that prevent contamination of the environment with human faeces. The study also showed improper disposal of children faeces in both open defaecation and open defaecation free communities as almost half of the respondents said nothing is done to the child faeces. Improper disposal of child faeces have negative implications on the environment (Okullo et al., 2017). Since children's faeces also contain germs like adult's faeces and it is essential to dispose them safely and quickly (Azage \& Haile, 2015; Harris et al., 2017).

Majority of the respondents admitted the use to open defaecate but the intervention of CLTS in open defaecation free communities have reduced the practice. The use of latrines have ensured a good sanitation, faecalconnected diseases prevention, or healthy environment such as cholera and diarrhoea (Azage \& Haile, 2015). The type of treatment method they employ in treating their water are filtration, boiling and addition of alum. These types of treatments are being used depending on the source of the water.

Microbial load in the drinking water from open defaecation communities was higher than open defaecation free communities. Hence, open defaecation practice leads to contamination of household water probable due to inadequate protection (poorly covered, uncovered or open) and unsanitary water collection and storage containers in the communities. Similarly, Tambekar \& Rajgire (2012) reported that drinking water in open defaecation free communities was $17 \%$ faecally contaminated whilst open defaecation was $48 \%$. There was significant positive correlation between E. coli and Salmonella spp implying common unhygienic practices cause their contamination in the drinking water. Unhygienic practices has contributed to the loads of E. coli and Salmonella spp which could originate from faecal matter from livestock, human, and pet. Whilst flies could have contaminated the drinking water with Shigella spp as a transmission vector from polluted faecal waste.

Microbial contamination of drinking water is caused by lack of hygienic practices and could lead diseases such as typhoid, dysentery and diarrhoea. Unsanitary ways of handling drinking water at household, including contaminated hands and dippers, 
and unsatisfactory cleaning of vessels, which lead to accumulation of sediments and pathogens. Also, clothing, hands, food, and utensils can play a role in water contamination, mostly when domestic hygiene and sanitation are poor which can lead to occurrence of sanitation-related diseases such as cholera and typhoid (Odeleye \& Idowu, 2015). This finding was lower than $71 \%$ E. coli occurrence in water samples in unproved water sources in Manonyane community in the Maseru District (Olowe et al., 2016).

\section{Conclusion}

The study showed there are no cultural issues hindering the people access and use of latrines in the communities. Microbial contamination of drinking water was high in open defaecation communities than open defaecation free communities. There is a good linkage between microbiological quality of the drinking and sanitation practices in the communities. Unhygienic practices has contributed to the E. coli and Salmonella spp count which could originate from faecal matter from livestock, human, and pet. Whilst flies could have contaminated the drinking water with Shigella spp as a transmission vector from polluted faecal waste. The microbial contamination of the drinking water can lead to water related diseases such as dysentery, typhoid and diarrhoea that can lead to disease burden in the communities. The adoption of the community led total sanitation can help reduce contamination of drinking water and incidences of waterborne disease. The study recommends that uunhygienic practices must be stopped and construction of latrines by every household should be encouraged in the open defaecation communities.

\section{Acknowledgement}

We wish to thank Mr. Elvis Kichana and Mr. Solomon Minyila of World Vision International for their immeasurable support. We are also grateful Mr. Dawuda Shaibu Y. Pumaaya of the Northern Regional Environmental Health and Sanitation Unit and Mr. Mohammed Zakaria, Dr. Ziblim A. Imoro and Mr. Fidelis Z. Tang of the University for Development Studies.

\section{Conflict of interest}

There is no conflicting interest amongst authors of this manuscript.

\section{References}

American Public Health Association (APHA) (2017) Standard methods for the examination of water and wastewater, $23^{\text {rd }}$ edn. American Public Health Association (APHA), Washington, D. C.

Azage, M. \& Haile, D. (2015) Factors associated with safe child feces disposal practices in Ethiopia: evidence from demographic and health survey. Arch Public Health 73, 40.

Bain, R., Cronk, R., Hossain, R., Bonjour, S., Onda, K., Wright, J., Yang, H., Slaymaker, T., Hunter, P., Pruss-Ustun, A. \& Bartram, J. (2014) Global assessment of exposure to faecal contamination through drinking water based on a systematic review. Tropical Medicine \& International Health 19 (8), 917 - 927.

BwIRE, B. (2010) Breaking shit taboos: CLTS in Kenya. In: Bongartz P, Musyoki SM, Ashley $\mathrm{H}$, editors, eds. Tales of Shit: Community-Led Total Sanitation in Africa. London: IIED, 91 $-96$.

GHANA STATISTICAL SERVICE (GSS) (2012) National population and housing census, 2010. Ghana Publishing Corporation, Accra.

Harris, M., Alzua, M. L., Osbert N. \& Pickering, A. J. (2017) Community-level sanitation coverage is more strongly associated with child growth and household drinking water quality than access to a private toilet in rural Mali. Environ Sci Technol 51, 7219 - 7227. 
Muhammed, A. U., Nicolas, G. \& Joachim, V. B. (2016) The impact of drinking water quality and sanitation behavior on child health: evidence from Rural Ethiopia, ZEF - Discussion Papers on Development Policy No. 221, Center for Development Research, Bonn, Germany.

Odeleye, F. O. \& Idowu, A. O. (2015) Bacterial pathogens associated with hand-dug wells in Ibadan city, Nigeria. African Journal of Microbiology Research 9 (10), 701 - 707.

Okullo, J. O., Moturi, W. N. \& OGendi, G. M. (2017) Open defaecation and its effects on the bacteriological quality of drinking water sources in Isiolo County, Kenya. Environ Health Insights 11, 1178630217735539.

Olowe, B., Oluyege, J. \& Famurewa, O. (2016) Prevalence of waterborne diseases and microbial assessment of drinking water quality in ado-ekiti and its environs, Southwestern, Nigeria. British Microbiology Research Journal 12 (2), 1 - 13.
Tambekar, D. H. \& Rajgire, A. V. (2012) Open defaecation: a source of fecal pollution in drinking water. Int $J$ Adv Pharma Biol Sci 2 (3), $214-223$.

UNITED NATIONS INTERNATIONAL CHILDREN'S EMERGENCY FUND (UNICEF) (2017) Why waste water? Release on World Water Day.

WHO/UNICEF (2015) Progress on sanitation and drinking water: 2015 update. Joint Monitoring Programme for Water Supply and Sanitation, Geneva, Switzerland: World Health Organization.

WORLD BANK (2015) World development report 2015: mind, society, and behavior, the World Bank, Washington, DC, USA, 2015.

\section{WORLD HEALTH ORGANISATION (WHO)} (2017) Drinking water fact sheets. www. who.int/mediacentre/factsheets/fs391/en/.Updated2017.

Received 11 May 20; revised 16 Dec 20. 